\title{
HARD TICK FAUNA (ACARI: IXODIDAE) IN DIFFERENT TYPES OF HABITATS IN THE CITY OF OSIJEK (EASTERN CROATIA)
}

\author{
Jelena Kovačević, Tomislav Bučanović \& StJepan KrČMaR* \\ Department of Biology, Josip Juraj Strossmayer University of Osijek, \\ Cara Hadrijana 8/A, HR-31000 Osijek, Croatia
}

Kovačević, J., Bučanović, T. \& Krčmar, S.: Hard tick fauna (Acari: Ixodidae) in different types of habitats in the city of Osijek (Eastern Croatia). Nat. Croat., Vol. 29, No. 1., 63-72, 2020, Zagreb.

A faunistic study of hard ticks was conducted from February 2019 to August 2019 in seven different habitats in the city of Osijek. In all, 664 specimens were collected and classified into 2 species and 2 genera. Ixodes ricinus (Linnaeus, 1758) is the most abundant species in the studied area with 493 specimens, followed by Haemaphysalis concinna Koch, 1844 with 171 specimens collected. The largest number of ticks was collected in July, in the larval stage. Statistically significant differences were observed in the number of specimens with respect to different habitat types and sampling months $(\mathrm{p}<0.05)$. The data collected constitute a pilot study of the hard tick population in the city of Osijek, the largest city in eastern Croatia, which is characterized by the largest number of green spaces and parks in Croatia.

Key words: hard ticks, Ixodes ricinus, Haemaphysalis concinna, Osijek, Croatia

Kovačević, J., Bučanović, T. \& Krčmar, S.: Fauna tvrdih krpelja (Acari: Ixodidae) različitih tipova staništa grada Osijeka (istočna Hrvatska). Nat. Croat., Vol. 29, No. 1., 63-72, 2020, Zagreb.

Istraživanja faune tvrdih krpelja provedena su od veljače do kolovoza 2019. godine na sedam različitih stanišnih tipova unutar grada Osijeka. Prikupljene su 664 jedinke, svrstane u 2 vrste i 2 roda. Vrsta Ixodes ricinus (Linnaeus, 1758) je najbrojnija vrsta na istraživanim lokalitetima s 493 skupljene jedinke, te slijedi Haemaphysalis concinna Koch, 1844 sa 171 jedinkom. Najveći broj krpelja skupljen je u srpnju, u razvojnom stadiju larve. Zabilježene su statistički značajne razlike u brojnosti jedinki uzorkovanih vrsta krpelja u odnosu na različite tipove staništa i mjesec uzorkovanja $(p<0,05)$. Skupljeni krpelji predstavljaju nulto stanje populacije tvrdih krpelja na području grada Osijeka, najvećeg grada istočnog dijela Hrvatske, grada s najviše zelenih površina i parkova u Hrvatskoj.

Ključne riječi: tvrdi krpelji, Ixodes ricinus, Haemaphysalis concinna, Osijek, Hrvatska

\section{INTRODUCTION}

Within the group of arthropods, ticks are gaining increasing attention because of their vector capabilities and the transmission of human and animal pathogens, including protozoa, viruses, bacteria, fungi and various types of infectious diseases (GooDMAN et al., 2005). This is precisely what makes them a worrying group of arthropods, which transmit more pathogens worldwide than any other group. Their growth and development are facilitated by the blood of the host (Durden, 2006). Tick bites can cause toxic reactions, allergic responses, even paralysis, and the resulting wounds can be potential entry points for secondary microbial infections (HADDAD et al., 2018). Glo-

\footnotetext{
* corresponding author: stjepan@biologija.unios.hr
} 
bally, they are the most important vectors in the spectrum of veterinary interests and the second most important after mosquitoes in the public health sector (DE LA FuENTE et al., 2008; MrLjaK et al., 2017). Tick-borne zoonoses have been known and studied since the second half of the 19th century (HoogstraAL, 1967). However, over the last two decades, there has been an increase in the number of newly discovered diseases and the number of reported cases of patients (PFÄFfle et al., 2013). Despite improvements in prevention and treatment, tick-borne encephalitis is the most common tick-transmitted disease in Central and Eastern Europe and Russia (Aмicizia et al., 2013). In the European Union between 2012 and 2016, 23 countries reported 12,500 tick-borne encephalitis cases of which $93 \%$ were confirmed cases, while $7 \%$ were probable cases (BEAuté et al., 2018). The annual notification rate fluctuated between 0.41 cases per 100,000 inhabitants in 2015 and 0.65 in 2013 in the European Union and the European Economic Area (BEAuté et al., 2018). Also, in Germany infection with tick-borne encephalitis virus showed a slight but significantly rising temporal trend from 2001 to 2018. Risk areas increased from 129 districts in 2007 to 161 in 2019 (Hellenbrand et al., 2019). In Croatia on average of 20 human cases of tick-borne encephalitis are reported each year, i.e. 0.26-1.05 cases per 100,000 inhabitants (ERber \& Vuković-Janković, 2020). Environmental factors in addition to sociodemographic changes, agrarian development, deforestation and other anthropogenically influenced modifications of ecological systems greatly affect the dynamics of tick populations and the spread of pathogens (Estrada-PeÑA \& DE LA Fuente, 2014). Therefore, interdisciplinary collaboration is needed to clarify changes in tick distribution. Data on hard tick fauna in eastern Croatia are rather scarce and reported in several published papers (KRČMAR, 2012; KRČMAR et al., 2014; KRČMAR, 2019). In recent studies on eastern Croatia, seven hard tick species from the genera Ixodes, Dermacentor and Haemaphysalis were recorded at 48 localities (KRČMAR, 2019), but the area of the city of Osijek was omitted from that study. Osijek is the largest city in eastern Croatia, with the largest number of green spaces and parks in Croatia; 17 parks with a total area of 394,000 $\mathrm{m}^{2}$. Therefore, the city of Osijek is an important demographic, industrial and cultural center, whose green spaces need to be monitored and recorded for the presence of ticks to prevent the emergence and spread of associated pathogens. Hence, the aim of this study was to investigate hard tick fauna diversity and the abundance of ticks in seven different types of habitats in Osijek.

\section{MATERIALS AND METHODS}

\section{Study area}

The study was conducted in seven different types of habitats within the city of Osijek. Woodland habitats as well as meadows are located on the periphery of the city, while there are recreational parks and dog parks in the city perimeter. Due to human activity and high dog density within the urbanized center, these areas are particularly suitable for sampling.

The first locality is King Tomislav Park (45 $\left.33^{\prime} 40.23^{\prime \prime} \mathrm{N} 18^{\circ} 41^{\prime} 29.51^{\prime \prime E}\right)$, classified as a Monument of Park Architecture. There are 83 taxa of shrubs and trees inside the park, such as common holly (Ilex aquifolium L.), field maple (Acer campestre L.) and eastern white pine (Pinus strobus L.).

The second locality is the flood defence embankment of the Drava River $\left(45^{\circ} 33^{\prime} 44.11^{\prime \prime} \mathrm{N}\right.$ $\left.18^{\circ} 42^{\prime} 56.77^{\prime \prime E}\right)$ - mesophilic meadows where the possibility of sampling largely depends 
on the water level of the Drava River and its maximums in water levels and flows during spring/early summer and fall.

The third locality is a riparian woodland near Osijek Zoo (4534'7.69"N 1841'20.68"E) located on the left bank of the Drava River. The study area is a type of willow and poplar flood woodland, however, due to the flood defence embankment along the left bank, the woodland is above groundwater level.

The fourth locality is a mesophilic meadow near the stadium Gradski vrt $\left(45^{\circ} 32^{\prime} 35.03 " \mathrm{~N} 18^{\circ} 41^{\prime} 36.04^{\prime \prime} \mathrm{E}\right)$. It is located on the periphery of the city just a few meters from the stadium and residential units along the southern bypass of Osijek.

The fifth locality is white willow and poplar riparian woodland near the Pampas shooting range $\left(45^{\circ} 34^{\prime} 5.94^{\prime \prime} \mathrm{N} 18^{\circ} 38^{\prime} 11.25^{\prime \prime} \mathrm{E}\right)$. It is surrounded by thoroughfares, residential areas and shopping centers.

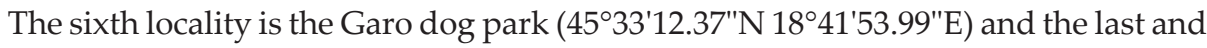
seventh locality is the Toti dog park $\left(45^{\circ} 33^{\prime} 29.42^{\prime \prime} \mathrm{N} 18^{\circ} 41^{\prime} 55.82^{\prime \prime E}\right)$ which are mowed relatively regularly and are quite frequently visited by dogs and their owners.

In the study area a continental climate prevails with an average annual rainfall of $700 \mathrm{~mm}$ to $800 \mathrm{~mm}$, while the average air temperature is $10.7^{\circ} \mathrm{C}$ (data from the Croatian Meteorological and Hydrological Service).

\section{Tick collection}

Hard tick sampling was performed over a seven-month period, from February to August 2019 with two field trips per month, with average sampling intervals of 15 days. It is important to keep an eye on the weather as it is essential to sample the ticks during dry and sunny days without precipitation.

Ticks were collected by the dragging-flagging method. Each sampling lasted 30 minutes per locality. Each sampling transect was $30 \mathrm{~m}$ long. All collected ticks were preserved in $96 \%$ ethanol solution. Identification and nomenclature followed that of Hillyard (1996) and Estrada-Peña et al. (2004).

\section{Data visualization and analysis}

Data were stored and analyzed in Excel and in programming language $\mathrm{R}$ ( $\mathrm{R}$ CoRE TeAm, 2018) and because of the non-Gaussian distribution of the data tested by the Shapiro-Wilk normality test $(\mathrm{p}<0.05)$; a non-parametric $\chi^{2}$ test was applied to conclude what the data differences were and ultimately a post-hoc $\chi^{2}$ test to determine between which samples statistically significant differences occurred (Agresti, 2007). Furthermore, the Sørensen index was used to describe and compare the similarity of the two samples within different habitat types (Durbešić, 1988).

\section{RESULTS AND DISCUSSION}

The processing and analysis of ticks collected in the area of the city of Osijek from February 2019 to August 2019 reveal the presence of 2 species, Ixodes ricinus (Linnaeus, 1758) and Haemaphysalis concinna Koch, 1844 in collected samples within 664 specimens. The most abundant species is $I$. ricinus with a prevalence of $74.25 \%$ (493 specimens), while the species H. concinna accounts for $25.75 \%$ (171 specimens) (Fig. 1). 


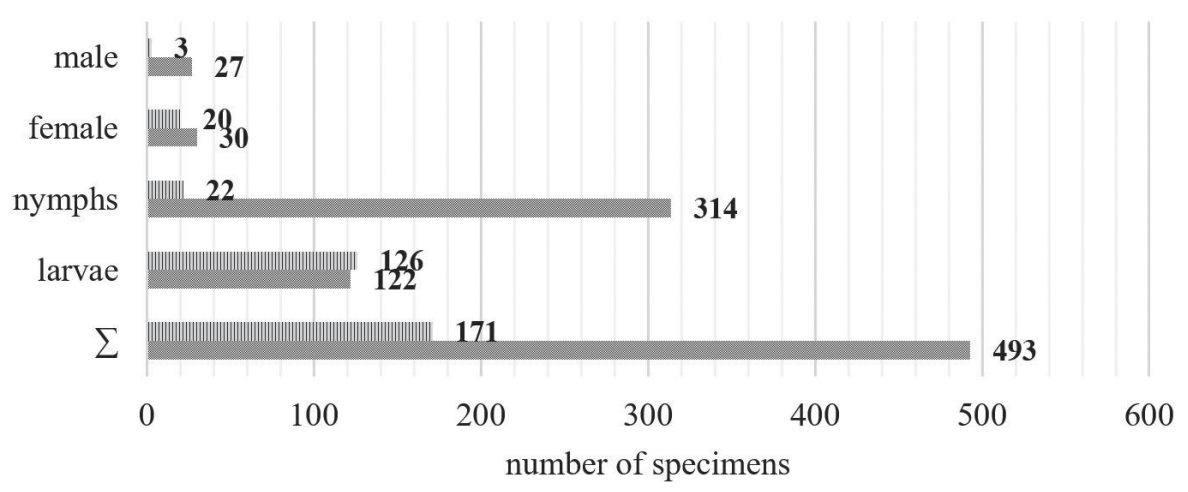

IIII Haemaphysalis concinna $\quad$ Ixodes ricinus

Fig. 1. Number of ticks classified by species and developmental stage sampled in the city of Osijek from February to August 2019.

The abundance of specimens in the nymphal stage is dominant, followed by the larval stage in the study area. The smallest abundance of sampled ticks is recorded in the adult stage, especially males (Fig. 1). Normally, adults and nymphs of the I. ricinus (common tick) are active between March or early April until early November for this climate zone (DAutel et al., 2008). However, 16 active nymphs and 2 adults ( $1 \delta$ and 1 ㅇ) of $I$. ricinus were collected and determined during February (Tab. 1). The activity of nymphs and adult ticks during the winter has also been observed in the forest habitats of the city of Berlin (DAutel et al., 2008). The premise for the early activity of $I$. ricinus is climate change and the trend of mild winters (GrAY et al., 2009). Also, climate change contributes to the spread of I. ricinus in areas that were previously unsuitable for this tick species such as the northernmost areas of Europe and northern Eurasian areas (DANTAs-Torres, 2015). During 2018 no significant deviations were observed in the amount of precipitation in this area, however, an air temperature anomaly of 2.0 ${ }^{\circ} \mathrm{C}$ was registered (Tab. 2). Likewise, the mean air temperature in February deviated from the average by $2.5^{\circ} \mathrm{C}$ (Tab. 2). Accordingly, it would be advisable to abandon the established practice of tick sampling from March to November, because, according to the data collected so far, their activity during the winter is expected and therefore increases the risk of tick-borne zoonoses. The seasonal activity of I. ricinus is characterized by two abundance peaks (in spring from March to May and in July), while the highest activity of H. concinna is recorded in May and July (Fig. 2). Adults and nymphs reach their activity peak in spring and early summer in northern and central parts of Europe, whereas in the case of larvae, it is in mid-summer (Gray et al., 2016). Also, in southern Italy, during summer very few nymphs and adult ticks of $I$. ricinus were recorded (Dantas-Torres \& Otranto, 2013). These data correspond with the data obtained in this study, where the highest activity in the nymphal and adult stages were recorded during May, while highest activity of the larval stage was recorded in July (Fig. 3). Further, no specimens of $H$. concinna were sampled until mid-April 2019 (Tab. 1), as expected since nymphs and adults of this species are active from April/May in Central Europe (Rubel et al., 2018). What deviates from the rule is the highest adult activity of 
H. concinna in July in Osijek (Fig. 3). Similarly, the highest activity of H. concinna in Hungary occurred from April to July (FöLDVÁRI \& FARKAS, 2005), although the activity is common throughout June for these areas (Rubel et al., 2018). The reason for this is the abrupt change in air temperature late in May (air temperature anomaly $-3.1^{\circ} \mathrm{C}$ ) and June (air temperature anomaly $3.0^{\circ} \mathrm{C}$ ) (Tab. 2) and probably the treatment of mosquitoes at the end of June. For the same reason, the total number of specimens collected in the month of June is much lower. The number of ticks collected in April is lower than in March (Tab. 1). The cause of the decreased number of collected specimens is inclement weather and frequent rainfall during April. $\chi^{2}$ test and post-hoc $\chi^{2}$ test show a statistically significant difference between the frequencies in most tick samples depending on the sampling month $\left(\chi^{2}=251.67, \mathrm{df}=6, \mathrm{p}<0.001\right)$.

Tab. 1. The number of collected hard ticks at seven sampling locations within the city of Osijek. Legend: + (female), $\hat{o}$ (male), n (nymph), 1 (larva).

\begin{tabular}{|c|c|c|c|c|c|c|c|}
\hline Species/ Months & II & III & IV & $\mathrm{V}$ & VI & VII & VIII \\
\hline \multicolumn{8}{|l|}{ King Tomislav Park } \\
\hline Ixodes ricinus (Linnaeus, 1758) & 0 & 0 & $1 \widehat{0}$ & 0 & 0 & 0 & 0 \\
\hline$\sum$ & 0 & 0 & 1 & 0 & 0 & 0 & 0 \\
\hline \multicolumn{8}{|c|}{ The flood defence embankment of the Drava River } \\
\hline $\begin{array}{l}\text { Haemaphysalis concinna Koch, } \\
1884\end{array}$ & 0 & 0 & 1 운 & 0 & 0 & 0 & 0 \\
\hline$\sum$ & 0 & 0 & 1 & 0 & 0 & 0 & 0 \\
\hline \multicolumn{8}{|l|}{ Woodland near Osijek Zoo } \\
\hline Ixodes ricinus (Linnaeus, 1758) & $\begin{array}{l}1 \hat{\jmath}, 1 \text {, } \\
16 \mathrm{n}\end{array}$ & $\begin{array}{l}6 \hat{\circ} \\
5+ \\
62 \mathrm{n}\end{array}$ & $\begin{array}{c}10 \hat{2}, 6 \circ, \\
57 \mathrm{n}\end{array}$ & $\begin{array}{c}2 \widehat{\lambda}, 20 \\
90 \mathrm{n}\end{array}$ & $\begin{array}{c}10 \hat{O}, 28 \mathrm{n} \\
21\end{array}$ & $\begin{array}{l}1 \hat{\jmath}, 3 \text {, } \\
15 \mathrm{n}, 641\end{array}$ & $2 \mathrm{n}, 141$ \\
\hline $\begin{array}{l}\text { Haemaphysalis concinna Koch, } \\
1884\end{array}$ & 0 & 0 & 29 & $\begin{array}{l}7 ㅇ, 2 \mathrm{n} \\
\quad 7 \mathrm{l}\end{array}$ & $2+, 91$ & $\begin{array}{l}10^{\top}, 3 \text {, } \\
9 \mathrm{n}, 1051\end{array}$ & $\begin{array}{c}1 \delta^{\lambda}, 4 n, \\
21\end{array}$ \\
\hline$\sum$ & 18 & 73 & 66 & 110 & 42 & 201 & 23 \\
\hline \multicolumn{8}{|c|}{ Woodland near Pampas shooting range } \\
\hline Ixodes ricinus (Linnaeus, 1758) & 0 & $30 \mathrm{n}$ & $\begin{array}{c}10,3 \text {, } \\
6 \mathrm{n}\end{array}$ & $\begin{array}{c}2 \AA, 4 \text { ㅇ, } \\
3 \mathrm{n}\end{array}$ & $4 \hat{\jmath}, 2+$ & 31 & 391 \\
\hline $\begin{array}{l}\text { Haemaphysalis concinna Koch, } \\
1884\end{array}$ & 0 & 0 & $1, 1 \mathrm{n}$ & $1 \mathrm{n}$ & 31 & $\begin{array}{c}10 \hat{2}, 4 \text { ㅇ, } \\
2 \mathrm{n}\end{array}$ & $3 n$ \\
\hline$\sum$ & 0 & 30 & 12 & 10 & 9 & 10 & 42 \\
\hline \multicolumn{8}{|l|}{ Garo dog park } \\
\hline Ixodes ricinus (Linnaeus, 1758) & 0 & 0 & $1 \delta, 2 \mathrm{n}$ & $\begin{array}{c}60^{\Uparrow}, 4 \text { ㅇ, } \\
3 \mathrm{n}\end{array}$ & 0 & 0 & 0 \\
\hline$\sum$ & 0 & 0 & 3 & 13 & 0 & 0 & 0 \\
\hline \multicolumn{8}{|c|}{ Mesophilic meadow near the Gradski vrt stadium } \\
\hline$\sum$ & 0 & & & & & & \\
\hline \multicolumn{8}{|l|}{ Toti dog park } \\
\hline$\sum$ & 0 & & & & & & \\
\hline
\end{tabular}


Tab. 2. Air temperature and precipitation amount anomalies in 2018 and 2019 in the city of Osijek (data from Croatian Meteorological and Hydrological Service).

\begin{tabular}{|l|c|c|c|c|c|c|c|c|}
\hline Year & 2018 & \multicolumn{7}{|c|}{2019} \\
\hline Months & & II & III & IV & V & VI & VII & VIII \\
\hline $\begin{array}{l}\text { Air temperature } \\
\left.\text { anomalies ( }{ }^{\circ} \mathbf{C}\right)\end{array}$ & 2.0 & 2.5 & 2.6 & 1.0 & -3.1 & 3.0 & 0.6 & 2.1 \\
\hline $\begin{array}{l}\text { Precipitation } \\
\text { amounts (percentile) }\end{array}$ & 50 & 39 & 3 & 76 & 98 & 72 & 58 & 68 \\
\hline Category & $\begin{array}{c}\text { extremely } \\
\text { warm/ } \\
\text { normal }\end{array}$ & $\begin{array}{c}\text { warm/ } \\
\text { normal }\end{array}$ & $\begin{array}{c}\text { warm/ } \\
\text { very } \\
\text { dry }\end{array}$ & $\begin{array}{c}\text { normal/ } \\
\text { wet }\end{array}$ & $\begin{array}{c}\text { very cold/ } \\
\text { very wet }\end{array}$ & $\begin{array}{c}\text { very } \\
\text { warm/ } \\
\text { normal }\end{array}$ & $\begin{array}{c}\text { normal/ } \\
\text { normal }\end{array}$ & $\begin{array}{c}\text { very } \\
\text { warm/ } \\
\text { normal }\end{array}$ \\
\hline
\end{tabular}

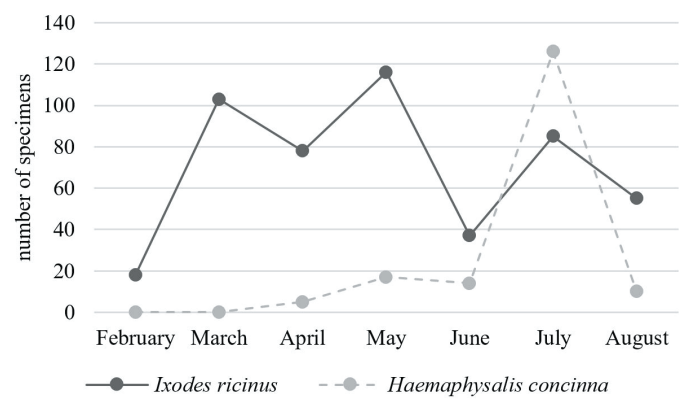

Fig. 2. Seasonal activity of hard ticks recorded in the city of Osijek from February to August 2019.

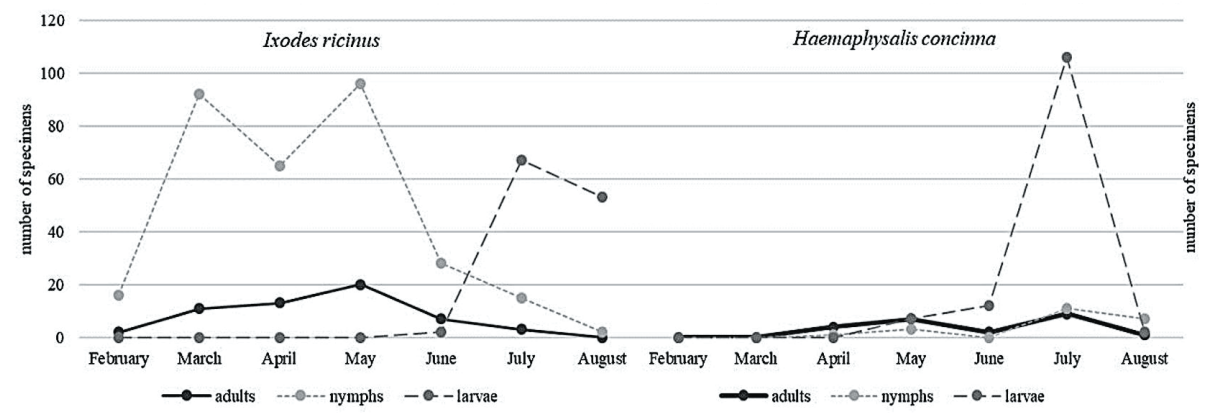

Fig. 3. Hard tick abundance in the city of Osijek from February to August 2019.

Forest habitats, with the largest number of sampled specimens (646 specimens, $97.28 \%$ ), stand out in the qualitative and quantitative composition of the tick fauna, precisely because of the larger number of suitable hosts. Within the parks, the largest number of collected ticks was in the Garo dog park. On the other hand, not a single tick was collected in the meadow near the Gradski vrt stadium or in the Toti dog park (Tab. 1). $\chi^{2}$ test and post-hoc $\chi^{2}$ test show a statistically significant difference between the frequencies in most of the tick samples depending on the sampling site $\left(\chi^{2}=1573.3, \mathrm{df}=4\right.$, $\mathrm{p}<0.001$ ), except between samples collected in King Tomislav Park and the flood defence 
embankment of the Drava River ( $p=1.00000)$. The Sørensen index values indicate the highest faunal similarity of the sampled tick species between the woodland areas $(100 \%)$. Similarly, the greatest similarity was observed between King Tomislav Park and Garo dog park (100\%). On the other hand, the similarity between King Tomislav Park and the woodland near Osijek Zoo is $66 \%$. Also, the same index value was recorded in the comparison of King Tomislav Park and the woodland near the Pampas shooting range. In addition, the woodland near Osijek Zoo and the woodland near the shooting range share a $66 \%$ similarity with the flood defence embankment of the Drava River and the Garo dog park. After the species I. ricinus and Dermacentor reticulatus, H. concinna is the third most abundant species in Central Europe (Rubel et al., 2018). In numerous studies, the share of $H$. concinna specimens among the ticks collected is usually around $2 \%$ (UsPENSKY, 2014). For example, a study conducted in Poland recorded 1,600 collected ticks, of which $2.7 \%$ belonged to $H$. concinna and $95 \%$ to I. ricinus (KIEwra et al., 2019). Additionally, in Slovakia, $1.3 \%$ of H. concinna and $98.6 \%$ of I. ricinus were collected (KAzIMírová et al., 2016). Generally, among all European hard tick species, I. ricinus was often recorded as the most abundant species in local tick fauna (EstradA-PeñA \& VenzaL, 2006). However, southward to Hungary the result was similar to the results of this study. The share of H. concinna was $17.8 \%$ and $78.6 \%$ of I.ricinus (HoRnoK et al., 2014). This indicates the widespread distribution of the species $H$. concina, a vector of various pathogens and agents of diseases, including Lyme borreliosis, tick-borne encephalitis virus, Rickettsia sibirica, Coxiella burnetii and Crimean-Congo hemorrhagic fever (Meng et al., 2016). The collected samples contained many $H$. concinna specimens (171 specimens), but not a single specimen of the species $D$. reticulatus, despite the high prevalence recorded in various habitats of Central Europe, including alluvial forests, wetlands, dry habitats and urban areas (RubeL et al., 2016). The small diversity of tick fauna in the area of the city of Osijek is not so surprising precisely because of the lack of tick species diversity in the larger urban areas of Croatia, such as the city of Zagreb. Within the different habitats at three popular recreational urban sites in the city of Zagreb in the period from 2016 to 2018, only one tick species, I. ricinus, was identified (Vucelja et al., 2019). Also, I. ricinus was the most common in urban areas of Germany, Poland, the Czech Republic and some other countries as well (UsPENSKY, 2014). Due to its wide distribution and large abundance $I$. ricinus is considered the most important vector of many zoonotic pathogens of viral and bacterial origin (TBEV, Anaplasma phagocytophilum, Borelia burgdorferi s.l., Francisella tularensis) in Croatia (Borčić et al., 1978; Jemeršıć et al., 2014; Huber et al., 2017; MrLjaK et al., 2017), as well as in many areas of Europe (Furness \& FuRnEss, 2018). The results of this study in the city of Osijek were confirmed by a recently published study in Vienna (Vogelgesang et al., 2020).

\section{CONCLUSIONS}

Due to their ability to transmit numerous pathogens and diseases, tick populations need to be continuously monitored and controlled at local and national level. Many hard-tick species, including I. ricinus and H. concinna, are well adapted to existing conditions in urban areas and thus pose a constant threat to human and domestic animal health. It is important to emphasize that the distribution of H. concinna is not monitored as a part of the VectorNet project (ECDC, 2019), despite its high prevalence in many large cities in Europe. Therefore, this species should be considered as a relevant species for risk assessments. 


\section{ACKNOWLEDGEMENTS}

This study was supported by the Croatian Science Foundation grants IP-2016-069988 "DNA barcoding of biodiversity of Croatian fauna" (CroBarFauna) and IP-201606-7456 "Prevalence and Molecular Epidemiology of Emerging and Reemerging Neuroinvasive Arboviral Infections in Croatia (CRONEUROARBO). Also, we thank anonymous reviewers for improvements to this manuscript.

Received December 16, 2019

\section{REFERENCES}

Agresti, A., 2007: An Introduction to Categorical Data Analysis, 2nd ed., John Wiley \& Sons, New York, $394 \mathrm{pp}$.

Amicizia, D., Domnich, A., Panatto, D., Lai, P.L., Cristina, L.M., Avio, U. \& Gasparini, R., 2013: Epidemiology of tick-borne encephalitis (TBE) in Europe and its prevention by available vaccines. Human Vaccines \& Immunotherapeutics 9, 1-9.

Beauté, J., Spiteri, G., Warns-Petit, E. \& Zeller, H., 2018: Tick-borne encephalitis in Europe, 2012 to 2016. Eurosurveillance 23, 1-9.

BorČić, B., AleraJ, B., ŽUtić, M. \& MiKAčIĆ, D., 1978: Uloga krpelja (Ixodidae) u podržavanju prirodnog žarišta tularemije u srednjoj Posavini. Veterinarski arhiv 48: 277-283.

Dantas-Torres, F. \& Otranto, D., 2013: Species diversity and abundance of ticks in three habitats in southern Italy. Ticks and Tick-borne Diseases 4: 251-255.

Dantas-Torres, F., 2015: Climate change, biodiversity, ticks and tick-borne diseases: the butterfly effect. International Journal for Parasitology: Parasites and Wildlife 4, 452-461.

Dautel, H., Dippel, C., Kammer, D., Werkhausena, A. \& Kahl, O., 2008: Winter activity of Ixodes ricinus in a Berlin forest. International Journal of Medical Microbiology 298, 50-54.

de la Fuente, J., Estrada-Pena, A., Venzal, J.M., Kocan, K.M. \& Sonenshine, D.E., 2008: Overview: Ticks as vectors of pathogens that cause disease in humans and animals. Frontiers in Bioscience 13, 6938-6946.

DURDEN, L.A., 2006: Taxonomy, host associations, life cycles and vectorial importance of ticks parasitizing small mammals. In: Morand, S., Krasnov, B. \& Poulin, R. (eds.) Micromammals and macroparasites: From evolutionary ecology to management. Springer, Tokyo, p.91-102.

Durbešić, P., 1988: Upoznavanje i istraživanje kopnenih člankonožaca. Mala ekološka biblioteka. Knjiga 4, Hrvatsko ekološko društvo, Zagreb, 77 pp.

Erber, W. \& Vuković-Janković, T., 2020: TBE in Croatia. Chapter 12b. In: Dobler, G., Erber, W., Bröker, M. \& Schmitt, H.J. (eds.) The TBE Book. $3^{\text {rd }}$. Ed. Singapore, Global Health Press, p. 191-193.

Estrada-Peña, A., Bouattour, A., Camicas, J.L. \& Walker, A.R., 2004: Ticks of Domestic Animals in the Mediterranean Region. A Guide to Identification of Species. University of Zaragoza, Zaragoza, $131 \mathrm{pp}$.

Estrada-Peña, A. \& Venzal, J.M., 2006: Changes in habitat suitability for the tick Ixodes ricinus (Acari: Ixodidae) in Europe (1990-1999). EcoHealth 3, 154-162.

Estrada-Peña, A. \& DE LA Fuente, J., 2014: The ecology of ticks and epidemiology of tick-borne viral diseases. Antiviral Research 108, 104-128.

European Centre for Disease Prevention and Control and European Food Safety Authority, 2019: Tick maps. Stockholm. https://ecdc.europa.eu/en/disease-vectors/surveillance-and-disease-data/tickmaps, 05.12.2019.

FöLDVÁRI, G. \& FARKAS, R., 2005: Ixodid tick species attaching to dogs in Hungary. Veterinary Parasitology 129, $125-131$.

Furness, R.W. \& Furness, E.N., 2018: Ixodes ricinus parasitism of birds increases at higher winter temperatures. Journal of Vector Ecology 43, 59-62.

Goodman, L.J., Dennis, T.D. \& Sonenshine, E.D., 2005: Tick-borne diseases of humans. Emerging Infectious Disease 11, 1808-1809.

Gray, J.S., Dautel, H., Estrada-PeÑa, A., Kahl, O. \& Lindgren, E., 2009: Effects of climate change on ticks and tick-borne diseases in Europe. Interdisciplinary Perspectives on Infectious Diseases 2009, 1-12.

GraY, J.S., Kahl, O., Lane, R.S., Levin, M.L. \& TsaO, J.I., 2016: Diapause in ticks of the medically important Ixodes ricinus species complex. Ticks and Tick-borne Diseases 5, 992-1003. 
Haddad, V. JR, Haddad, M.R., Santos, M. \& CARdoso, J.L.C., 2018: Skin manifestations of tick bites in humans. Brazilian Annals of Dermatology 93, 251-255.

Hellenbrand, W., Kreusch, T., Böhmer, M.M., Wagner-Wiening, C., Dobler, G., Wichmann, O. \& AlTMANN, D., 2019: Epidemiology of Tick-borne encephalitis (TBE) in Germany, 2001-2018. Pathogens 8, 1-16.

Hillyard, P.D., 1996: Ticks of North-West Europe. Keys and Notes for Identification of the Species. Synopses of the British Fauna (New Series) 52. Field Studies Council, Shrewsbury, 178 pp.

HoogstraAl, H., 1967: Ticks in relation to human diseases caused by Rickettsia species. Annual Review of Entomology 12, 377-420.

Hornok, S., Meli, M.L., Gönczi, E., Halász, E., Takács, N., Farkas, R. \& Hofmann-Lehmann, R., 2014: Occurrence of ticks and prevalence of Anaplasma phagocytophilum and Borrelia burgdorferi s.l. in three types of urban biotopes: forests, parks and cemeteries. Ticks and Tick-borne Diseases 5, 785-789.

Huber, D., Reil, I., Duvnjak, S., Jurković, D., Lukačević, D., Pilat, M., Beck, A., Mihaljević, Ž., Vojta, L., Polkinghorne, A. \& Beck, R., 2017: Molecular detection of Anaplasma platys, Anaplasma phagocytophilum and Wolbachia sp. but not Ehrlichia canis in Croatian dogs. Parasitology Research 116, 3019-3026.

Jemeršić, L., DežĐek, D., Brnić, D., Prić, J., Janicki, Z., Keros, T., Roić, B., Slavica, A., Terzić, S., KonjevIĆ, D. \& BECK, R., 2014: Detection and genetic characterization of tick borne encephalitis virus (TBEV) derived from ticks removed from red foxes (Vulpes vulpes) and isolated from spleen samples of red deer (Cervus elaphus) in Croatia. Ticks and Tick- borne Diseases 5, 7-13.

Kazimírová, M., Hamšíková, Z., Kocianová, E., Marini, G., Mojšová, M., Mahríková, L., Berthová, L., Slovák, M. \& Rosá, R., 2016: Relative density of host-seeking ticks in different habitat types of south-western Slovakia. Parasites \& Vectors 9, 101.

Kiewra, D., CzuŁowska, A., Dyczko, D., Zieliński, R. \& Plewa-Tutaj, K., 2019: First record of Haemaphysalis concinna (Acari: Ixodidae) in Lower Silesia, SW Poland. Experimental and Applied Acarology 77, 449-454.

KRČMAR, S., 2012: Hard ticks (Acari, Ixodidae) of Croatia. ZooKeys 234, 19-57.

KrČMAR, S., Vereš, M. \& Trilar, T., 2014: Fauna of hard ticks (Acari: Ixodidae) in different habitats in Croatian part of Baranja. Šumarski list 138, 309-314.

KRČMAR, S., 2019: Diversity, ecology, and seasonality of hard ticks (Acari: Ixodidae) in eastern Croatia. Journal of Vector Ecology 44, 18-29.

Meng, H., Xu, S., Zhijun, Y., Li, N., Wang, R., Gao, X., YAnG, X. \& LiU, J., 2016: Abundance and seasonal activity of Haemaphysalis concinna (Acari: Ixodidae) at the border between China and Russia in Northern Inner Mongolia, China. Parasites and Vectors 9, 1.

Mrljak, V., Kuleš, J., Mihaljević, Ž., Torti, M., Gotić, J., Crnogaj, M., ŽıvičnjaK, T., Mayer, I., Šmit, I., Bhide, M. \& BARIć RAFAJ, R., 2017: Prevalence and geographic distribution of vector-borne pathogens in apparently healthy dogs in Croatia. Vector Borne Zoonotic Diseases 17, 398-408.

Pfäffle, M., Littwin, N., Muders, S.V. \& Petney, T.N., 2013: The ecology of tick-borne diseases. International Journal for Parasitology 43, 1059-1077.

R Core TeAm, 2018: R: A language and environment for statistical computing. R Foundation for Statistical Computing, Vienna, Austria, 2673 pp.

Rubel, F., Brugger, K., Pfeffer, M., Chitimia-Dobler, L., DidyK, Y.M., Leverenz, S., Dautel, H. \& Kahl, O., 2016: Geographical distribution of Dermacentor marginatus and Dermacentor reticulatus in Europe. Ticks and Tick-borne Diseases 7, 224-233.

Rubel, F., Brugger, K., Walter, M., Vogelgesang, J.R., Didyk, Y.M., Fu, S. \& Kahl, O., 2018: Geographical distribution, climate adaptation and vector competence of the Eurasian hard tick Haemaphysalis concinna. Ticks and Tick-borne Diseases 9, 1080-1089.

UsPeNSKY, I., 2014: Tick pests and vectors (Acari: Ixodoidea) in European towns: Introduction, persistence and management. Ticks and Tick-borne Diseases 5, 41-47.

Vogelgesang, J.R., Walter, M., Kahl, O., Rubel, F. \& Brugger, K., 2020: Long-term monitoring of the seasonal density of questing ixodid ticks in Vienna (Austria): setup and first results. Experimental and Applied Acarology 81, 409-420.

Vucelja, M., Bjedov, L., Boljfetić, M., Klobučar, A., Krčmar, S., Borak, S., Modrić, M., Juričić, K., Peleš, V., Margaletić, J. \& Vilibić ČAvleK, T., 2019: Monitoring of hard ticks at urban recreational sites in the City of Zagreb from 2016 to 2018. Infektološki glasnik 39, 33-39. 
